\title{
Identifikasi Karakteristik Ruang Bersama pada Permukiman Nelayan Untuk Optimalisasi Peremajaan Permukiman dengan Konsep Co-Living (Studi Kasus Kelurahan Kangkung, Kota Bandar Lampung)
}

\author{
Hafi Munirwan $^{1 *}$, Antusias Nurzukhrufa ${ }^{2}$, Fadila Septiandiani ${ }^{2}$, Cindy Dwi Islami ${ }^{1}$ \\ ${ }^{1}$ Program Studi Perencanaan Wilayah dan Kota, Institut Teknologi Sumatera, Lampung Selatan, Indonesia \\ ${ }^{2}$ Program Studi Arsitektur, Institut Teknologi Sumatera, Lampung Selatan, Indonesia \\ *Correspondence email:hafi.munirwan@pwk.itera.ac.if
}

\begin{abstract}
Abstrak. Perumahan dan permukiman merupakan kebutuhan dasar setiap manusia sebagai tempat tumbuh dan berkembang. Di negara berkembang, pertambahan penduduk yang pesat mengakibatkan kelangkaan lahan dan perumahan, terutama bagi masyarakat berpenghasilan rendah. Sehingga, permukiman kumuh tumbuh di atas, tepi, dataran, perbukitan dan daerah rawan bencana. Berbagai inisiatif peremajaan permukiman kumuh telah dilakukan, namun belum sepenuhnya berhasil menghilangkan kekumuhan. Keterbatasan sumberdaya kelembagaan dan pendanaan menuntut adanya inovasi pendekatan dalam meremajakan permukiman kumuh agar lebih efisien, yaitu berdampak signifikan bagi masyarakat. Karakteristik permukiman kumuh yang padat dan memiliki luasan area hunian terbatas juga menuntut adanya inovasi untuk memenuhi standar hunian layak. Disamping itu, nilai kebersamaan dan tingginya interaksi sosial antar warga kampung kota merupakan potensi yang dapat diintegrasikan dalam peremajaan permukiman kumuh. Sejalan dengan tantangan dan potensi tersebut, co-living, konsep hidup bersama, dengan berbagi ruang untuk penggunaan secara bersama, merupakan pendekatan yang dapat diterapkan dalam upaya peremajaan permukiman. Sebagai negara maritim dan kepulauan, salah satu karakteristik permukiman yang kerap berkembang di Indonesia adalah permukiman nelayan di kawasan pesisir. Dalam penelitian ini dilakukan studi terhadap ruang-ruang bersama di permukiman nelayan Kelurahan Kangkung, Bandar Lampung. Ruang bersama ini biasa digunakan oleh masyarakat untuk berinteraksi atau melakukan aktivitasnya baik saat pagi, siang, sore atau malam hari. Tujuan dari penelitian ini adalah untuk mengidentifikasi karakteristik ruang bersama pada permukiman nelayan, serta karakteristik penggunanya. Adapun ruang bersama ini dapat diprioritaskan penanganannya untuk memperbaiki kondisi sosial dan ekonomi masyarakat, sekaligus memberikan dampak yang signifikan tidak hanya bagi individu, namun juga bagi kelompok masyarakat yang luas. Metode penelitian yang digunakan dalam penelitian ini adalah pendekatan induktif kualitatif, dengan data bersumber dari observasi lapangan dan wawancara dengan pemangku kepentingan di permukiman nelayan, baik dari perwakilan masyarakat maupun pemerintah. Hasil penelitian ini telah mengidentifikasi setidaknya terdapat lima ruang bersama yang terdapat di permukiman nelayan Kelurahan Kangkung, yaitu pasar, pelabuhan dan Tempat Pelelangan Ikan (TPI), area tepi laut, koridor jalan dan toilet umum.
\end{abstract}

Kata kunci: peremajaan kota; peremajaan permukiman; ruang bersama, co-living; intensifikasi ruang

Abstract. Housing and settlements are basic needs of every human being as a place to grow and develop. In developing countries, rapid population growth results in scarcity of land and housing, especially for low-income people. Thus, slums grow on the top, edges, plains, hills and disaster-prone areas. Various initiatives to rejuvenate slums have been carried out, but have not completely succeeded in eliminating slums. Limited institutional and funding resources require an innovative approach in rejuvenating slum settlements to be more efficient, which has a significant impact on the community. The characteristics of slum settlements that are dense and have a limited residential area also require innovation to meet decent housing standards. In addition, the value of togetherness and the high level of social interaction between residents of urban villages is a potential that can be integrated in the rejuvenation of slums. In line with these challenges and potentials, co-living, the concept of living together, by sharing space for common use, is an approach that can be applied in efforts to rejuvenate settlements. As a maritime and archipelagic country, one of the characteristics of settlements that often develop in Indonesia is fishermen's settlements in coastal areas. In this study, a study was conducted on the common spaces in the fishermen's settlement of Kangkung Village, Bandar Lampung. This common room is usually used by the community to interact or carry out their activities either in the morning, afternoon, evening or night. The purpose of this study is to identify the characteristics of the common space in fishing settlements, as well as the characteristics of its users. The handling of this common space can be prioritized to improve the social and economic conditions of the community, while at the same time providing a significant impact not only for individuals, but also for wider community groups. The research method used in this study is a qualitative inductive approach, with data sourced from field observations and interviews with stakeholders in fishing settlements, both community and government representatives. The results of this study have identified at least five shared spaces in the fishing settlements of Kangkung Village, namely markets, ports and fish auction sites (TPI), waterfront areas, road corridors and public toilets.

Keywords: urban rejuvenation; rejuvenation of settlements; common room, co-living; space intensification

\section{PENDAHULUAN}

Perumahan dan permukiman merupakan kebutuhan dasar setiap manusia sebagai tempat tumbuh dan berkembang. Seiring dengan bertambahnya jumlah penduduk perkotaan, kebutuhan akan hunian turut mengalami peningkatan. Lebih luas lagi, kebutuhan 
ruang turut meningkat, tidak hanya sebagai tempat tinggal, namun juga meliputi fasilitas pendukung untuk aktivitas sosial, agama, pendidikan, kesehatan, ekonomi, serta transportasi (Rahmawati, 2018).

Pertambahan penduduk yang pesat mengakibatkan kelangkaan lahan perkotaan yang bersifat terbatas (finite resource). Khususnya di negara berkembang yang memiliki proporsi masyarakat berpenghasilan rendah (MBR) tinggi, penyediaan akses terhadap rumah yang layak merupakan suatu tantangan tersendiri. Keterbatasan akses terhadap permukiman layak ini kemudian memicu tumbuhnya kawasan permukiman kumuh (slum) dan liar (squatter) yang dicirikan dengan ketidak sesuaian lokasi dengan peruntukan ruang dan kualitas hunian yang buruk (Heryati, 2009). Sebagai contoh fisik bangunan rumah serta sirkulasi dan pencahayaan yang buruk, dan tidak memadainya ketersediaan prasarana dasar seperti air bersih, sanitasi, persampahan, maupun listrik. Adapun kondisi permukiman yang buruk mempengaruhi produktivitas dan kualitas hidup masyarakat. Sehingga, diperlukan peremajaan sebagai suatu upaya untuk mengoptimalisasi kembali lahan yang telah mengalami degradasi fungsi ruang (Munirwan et al., 2020). Secara umum, permukiman kumuh ini tumbuh di berbagai area, diantaranya tumbuh di atas, tepi, dataran, perbukitan dan daerah rawan bencana (Permen PUPR No. 2/PRT/M/2016 Tentang Peningkatan Kualitas Terhadap Perumahan Kumuh Dan Permukiman Kumuh).

Berbagai inisiatif dilakukan untuk mengentaskan kawasan kumuh, sejak zaman Belanda. diantaranya program "Kampong Verbeterring", diikuti oleh Kampung Improvement Program (KIP), Proyek Penanggulangan Kemiskinan di Perkotaan (P2KP), dan inisiatif-inisiatif lainnya, namun belum berhasil mengentaskan kekumuhan secara keseluruhan. Pada tahun 2014, luas kawasan kumuh perkotaan di Indonesia masih menyentuh angka $38.431 \mathrm{Ha}$ (Kementerian Pekerjaan Umum dan Perumahan Rakyat, 2015). Salah satu target di sector permukiman adalah pengentasan permukiman kumuh menjadi 0\% luas Kawasan kumuh perkotaan, yang turut tertuang dalam target 100-0-100 dalam Rencana Pembangunan Jangka Menengah Nasional (RPJMN) 2015-2019 (Kementerian Pekerjaan Umum dan Perumahan Rakyat, 2015). Selain itu, pengentasan permukiman kumuh juga merupakan salah satu target yang tertuang dalam Sustainable Development Goals (SDGs).

Keterbatasan sumberdaya kelembagaan maupun anggaran merupakan salah satu tantangan dalam penanganan permukiman kumuh, dimana laju penanganan permukiman kumuh tidak seimbang dibandingkan dengan pertambahan kawasan kumuh. Hasil kajian yang dilakukan oleh Kementerian Pekerjaan Umum pada tahun 2015 menyatakan bahwa kebutuhan dana untuk penanganan permukiman kumuh pada tahun 2015-2019 mencapai Rp. 215,7 T, dengan kemampuan fiskal pemerintah pusat dan daerah masing-masing sebesar Rp. 44,9 T dan Rp. 0,7 T, atau masih terdapat gap kebutuhan pendanaan sebesar Rp. 170,2 T atau berkisar di angka $25 \%$ dari total kebutuhan pembiayaan (Kementerian Pekerjaan Umum dan Perumahan Rakyat, 2015). Sehingga, diperlukan inovasi pendekatan yang mengedepankan efisiensi dalam mengentaskan permukiman kumuh. Salah satu inovasi yang dapat didorong adalah adalah penekanan pada aspek nilai guna, artinya penanganan harus tepat sasaran dan berdampak terhadap kehidupan masyarakat luas. Dalam hal ini, penanganan peremajaan permukiman kumuh yang berfokuskan pada ruang bersama, ruang yang digunakan secara bersama oleh komunitas/kelompok masyarakat, menjadi salah satu hal yang dapat didorong. Ruang bersama memiliki berbagai fungsi baik secara sosial, sebagai contoh sebagai tempat untuk berinteraksi antar warga, bermain bagi anak, maupun secara ekonomis sebagai tempat untuk bekerja baik dengan berjualan makanan maupun barang di koridor jalan, maupun di pasar. Sehingga, perbaikan yang berfokus pada ruang bersama tidak hanya berdampak bagi kelompok masyarakat luas, namun juga dapat memperbaiki kondisi sosial dan ekonomi masyarakat.

Salah satu karakteristik dari permukiman kumuh adalah luas lahan yang terbatas, atau dibawah standar luasan minimum hunian layak (Heryati, 2009). Kondisi rumah yang sempit ini "memaksa" masyarakat untuk melaksanakan aktivitas yang umumnya dilakukan di dalam rumah ke luar rumah. sebagai contoh memasak dan makan, menerima tamu, dan memarkir kendaraan pada koridor jalan, yang digunakan secara bersama oleh masyarakat untuk berbagai fungsi. Kondisi ini, kemudian pula dengan gaya hidup masyarakat di kampung kota yang cenderung hidup bersosialisasi dan memiliki interaksi sosial yang tinggi.

Terminologi co-living berasal dari kata "communal" dan "living" (Hoppenbrouwer, 2019). Adapun pendekatan ini mendorong pendekatan berbagi ruang antar masyarakat, yang saat ini mulai populer didorong tidak hanya karena lebih efisien dari segi ruang maupun biaya, namun juga mendorong adanya interaksi antar masyarakat. Pada dasarnya, konsep co-living ini bukanlah hal yang baru terutama di dalam kehidupan kampung kota, dikarenakan pada kenyataannya nilai ini sudah lama tumbuh dan dipraktikan dalam kehidupan di kampung kota seiring dengan gaya hidup bergotong royong. Sehingga, mendorong pengoptimalan konsep ini pada dasarnya selaras dengan kondisi masyarakat kampung kota.

Selain itu, dalam konteks permukiman yang memiliki luasan lahan terbatas, konsep co-living juga relevan untuk diterapkan, dimana sebagian fungsi di dalam rumah dapat dipindahkan ke luar rumah, dan diakomodasi pada ruang-ruang bersama. Hal ini sebenarnya sudah diterapkan dalam kehidupan seharihari pada kehidupan di kampung kota, seperti memasak 
dan makan, menerima tamu, dan memarkir kendaraan pada koridor jalan yang digunakan secara bersama oleh masyarakat. Sehingga, fungsi yang tidak dapat terpenuhi di dalam rumah diarahkan untuk diakomodasi pada ruang-ruang bersama. Sehingga, meski luasan rumah yang terbatas, namun seluruh fungsi rumah dapat terpenuhi di luar rumah. Sebagai contoh adalah penyesuaian desain koridor jalan yang akomodatif terhadap berbagai aktivitas, seperti: memasak, makan bersama, ruang bermain anak, atau penyediaan toilet umum. Sehingga, ruang dapur, makan maupun toilet yang umumnya berada di dalam rumah dapat diakses secara layak di luar rumah.

Sebagai negara kepulauan, salah satu bentuk permukiman yang banyak tumbuh di Indonesia adalah permukiman nelayan yang berada di kawasan pesisir (Permen PUPR No. 2/PRT/M/2016 Tentang Peningkatan Kualitas Terhadap Perumahan Kumuh Dan Permukiman Kumuh, 2016). Seiring dengan itu, permukiman kumuh tumbuh akibat kondisi sosial ekonomi masyarakat yang rendah.

Penelitian ini bertujuan untuk mengidentifikasi berbagai karakteristik ruang bersama dan penggunanya, khususnya dalam konteks permukiman nelayan. Ruang bersama dalam penelitian ini adalah ruang yang digunakan oleh kelompok masyarakat tertentu untuk berinteraksi atau melakukan aktivitasnya saat pagi, siang, sore atau malam hari. Adapun hasil kajian ini diharapkan dapat menjadi dasar pemrioritasan dalam peremajaan pada ruang berrsama agar peremajaan yang dilakukan berdampak secara signifikan tidak hanya pada individu, namun pada masyarakat luas, serta dapat berkontribusi terhadap perbaikan kondisi sosial dan ekonomi.

\section{METODE}

Pendekatan penelitian yang digunakan dalam penelitian ini adalah pendekatan induktif. Pendekatan induktif merupakan pendekatan yang digunakan dengan berpikir berdasarkan hal-hal khusus ke umum serta meliputi proses penalaran atas fenomena yang ada (Anggito dan Setiawan, 2018). Adapun dalam penelitian ini, fenomena yang dikaji adalah berkaitan dengan karakteristik ruang bersama di permukiman nelayan. Selain itu, metode penelitian yang digunakan dalam penelitian ini adalah metode kualitatif, dengan teknik pengumpulan data bersumber dari observasi dan wawancara dengan pemangku kepentingan di permukiman nelayan, baik dari masyarakat maupun pemerintah.

Disamping itu, penelitian ini dilakukan dengan menggunakan metode studi kasus, dengan mengangkat Kelurahan Kangkung, Kota Bandar Lampung sebagai lokasi studi. Hal ini didasari oleh data KOTAKU tahun 2018 yang mengkategorisasikan Kelurahan Kangkung sebagai Kawasan kumuh di Bandar Lampung. Selain itu, keunikan lokasi studi dibandingkan lokasi Kawasan kumuh lainnya adalah pada Kelurahan Kangkung, kawasan kumuh ini oleh masyarakat nelayan. Hal ini tidak terlepas dari lokasi studi yang berada di sekitar area pasar, Tempat Pelelangan Ikan (TPI), serta pelabuhan nelayan.

\section{HASIL DAN PEMBAHASAN}

Kelurahan Kangkung mulai berkembang pada seiring dengan adanya aktivitas pada pasar dan Tempat Pelelangan Ikan (TPI). Adapun permukiman nelayan kemudian mengalami perkembangan terutama masyarakat yang beraktivitas di sekitar pasar dan TPI, baik nelayan yang berlayar dan memasok sumber daya alam laut ke pasar dan TPI, maupun pedagang, serta pelaku transportasi seperti becak, angkutan umum maupun mobil pick-up.

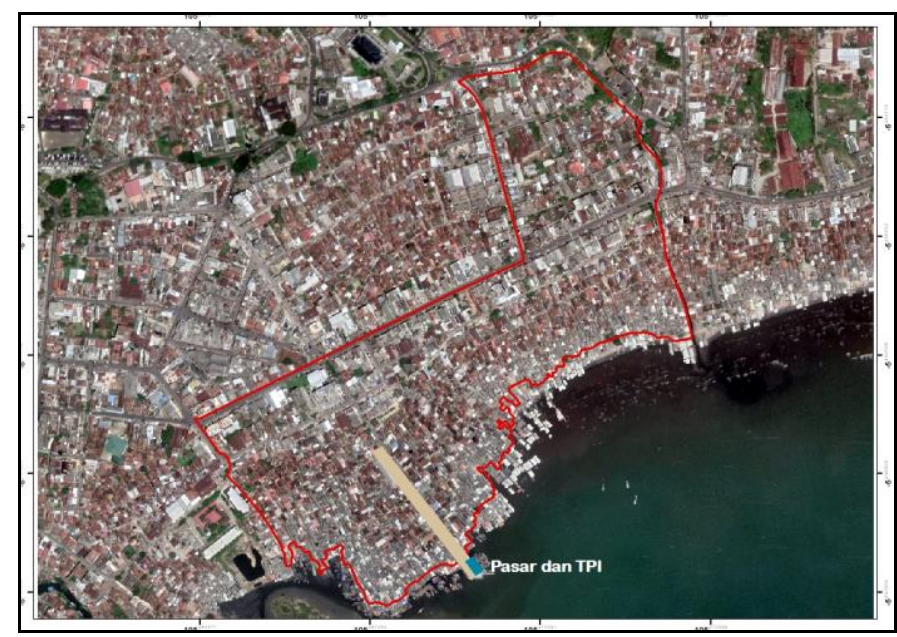

Gambar 1. Peta Administrasi Kelurahan Kangkung Sumber: diolah dari Citra Google Earth, 2021

\section{Karakteristik Ruang Bersama Di Permukiman Nelayan, Kangkung, Bandar Lampung}

Berdasarkan hasil observasi lapangan yang dilakukan serta penggalian informasi melalui wawancara, teridentifikasi lima ruang bersama yang terdapat di Kelurahan Kangkung. Ruang bersama ini merupakan ruang yang digunakan secara bersama oleh berbagai karakteristik pengguna, baik nelayan, pedagang, anak-anak, serta ibu-ibu dalam keseharian mereka. Adapun lima ruang bersama tersebut adalah pasar, pelabuhan dan Tempat Pelelangan Ikan (TPI), area tepi laut, koridor jalan dan toilet umum

\section{Pasar}

Salah satu ruang yang digunakan secara bersama di Kelurahan Kangkung adalah Pasar Gudang Lelang. Pada pasar ini komoditas yang dijual berupa hasil tangkapan laut, sayuran, buah-buahan, serta yang menjadi ciri khas pasar tersebut adalah olahan ikan laut berupa otak-otak. Pada jam operasi optimalnya, yaitu pagi hingga sore hari, pasar ini ramai digunakan secara bersama baik oleh pedagang, pembeli, penyedia jasa becak. ojek dan oleh nelayan untuk mendistribusikan 
hasil tangkapan lautnya. Adapun secara fungsi, pasar berperan untuk menunjang kegiatan ekonomi masyarakat, baik nelayan, pedagang, pelaku transportasi, maupun masyarakat sebagai konsumen.

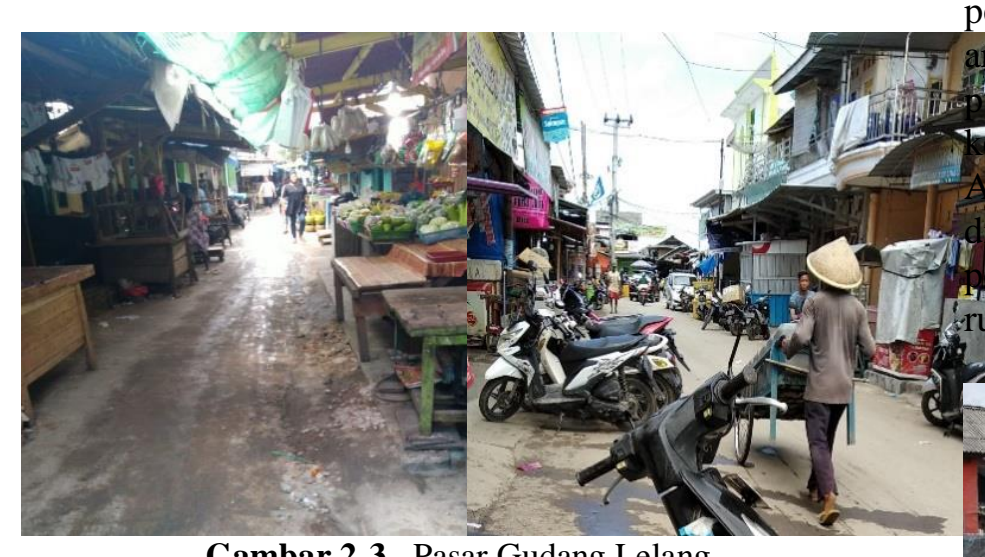

Gambar 2-3. Pasar Gudang Lelang

*) sumber: Observasi Lapangan, 2021

\section{Pelabuhan dan TPI}

Pelabuhan Gudang Lelang sudah ada sejak abad ke-19 dan menjadi tempat bersandarnya kapal-kapal nelayan untuk bongkar muat hasil tangkapan laut. Tangkapan laut yang didistribusikan pada pelabuhan ini sangat beragam, baik ikan, cumi, udang, serta komoditas tangkapan laut lainnya. Selain berfungsi sebagai pelabuhan, ruang ini juga berfungsi sebagai TPI, dimana pelelangan ikan dilakukan oleh nelayan dan pedagang yang membeli ikan untuk kemudian dijual kembali.

Secara umum, Pelabuhan dan TPI Gudang Lelang beroperasi selama $24 \mathrm{Jam}$, namun paling ramai aktivitas terutama pada pagi dan sore hari. Secara fungsi, pelabuhan dan TPI ini merupakan bagian yang tidak terpisahkan dari Pasar Gudang Lelang, dimana pelabuhan dan TPI ini merupakan penunjang yang turut berkontribusi sebagai ruang untuk kegiatan ekonomi baik bagi nelayan, pedagang, dan masyarakat sebagai konsumen.

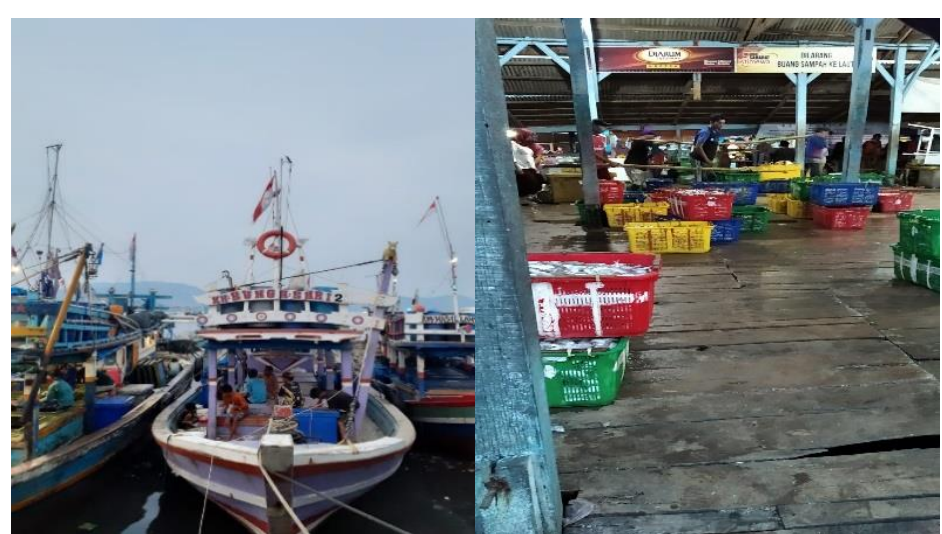

Gambar 4-5. Pelabuhan dan TPI

*) sumber: Observasi Lapangan, 2021 merupakan ruang yang umum digunakan oleh anak-anak sebagai ruang untuk melakukan berbagai aktivitas seperti berkumpul, bermain bola, bermain sampan dan berenang. Keterbatasan ruang terbuka publik pada permukiman nelayan yang padat penduduk, menjadikan a ublik yang dapat digunakan untuk memenuhi butuhan sosial anak untuk tumbuh dan berkembang. dapun ruang ini umumnya digunakan oleh anak-anak sore hari. Sehingga, area tepi laut, dalam konteks rmukiman nelayan, berkontribusi terhadap pemenuhan uang untuk fungsi sosial.
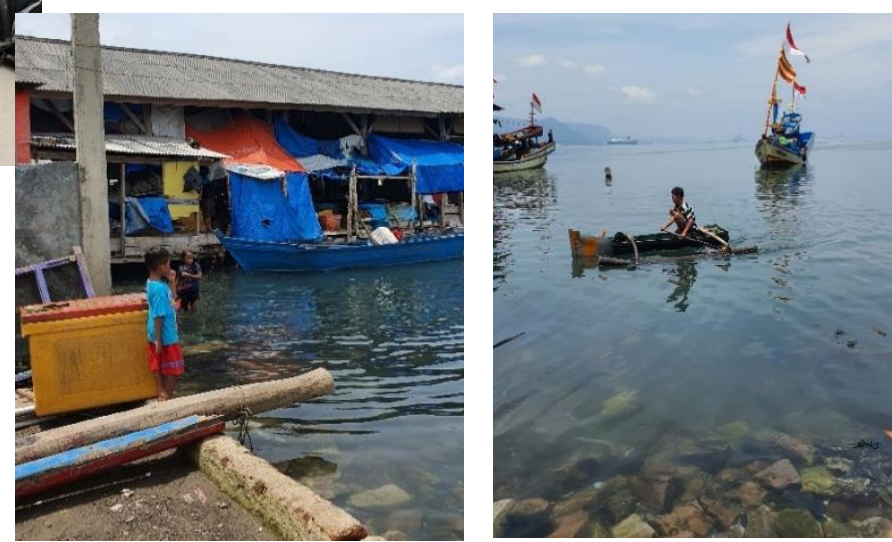

Gambar 6-7. Area Tepi Laut

*) sumber: Observasi Lapangan, 2021

\section{Koridor Jalan.}

Salah satu ruang bersama lain yang teridentifikasi dalam penelitian ini adalah ruang koridor jalan. Karakteristik dari koridor jalan pada permukiman nelayan Kangkung memiliki lebar berkisar antara 1-2meter, yang hanya bisa diakses secara terbatas oleh pejalan kaki, ataupun kendaraan roda dua. Selain berfungsi sebagai ruang untuk mobilisasi manusia dan barang, pada permukiman nelayan, koridor jalan juga memiliki fungsi-fungsi lain, diantaranya sebagai tempat berinteraksi bagi masyarakat, tempat untuk memarkir kendaraan, tempat untuk berjualan, serta untu melakukan usaha rumahan seperti fillet dan menjemur ikan.

Ruang koridor jalan ini umumnya ramai digunakan oleh anak-anak sebagai alternatif tempat berkumpul dan bermain. Disamping itu, ruang koridor jalan ini juga ramai digunakan oleh ibu-ibu sebagai tempat berinteraksi, maupun untuk kegiatan ekonomi seperti berdagang, menjemur serta fillet ikan untuk dapat dijual kembali. Ruang koridor jalan ini ramai digunakan di setiap waktu, dengan jam aktivitas puncak adalah pagi hingga sore hari. Berdasarkan hasil kajian tersebut, teridentifikasi peran koridor jalan tidak hanya untuk pemenuhan kebutuhan sosial sekaligus ekonomi bagi masyarakat.

\section{Area Tepi Laut}

Ruang bersama lain yang teridentifikasi dalam penelitian ini adalah area tepi laut. Area tepi laut ini 


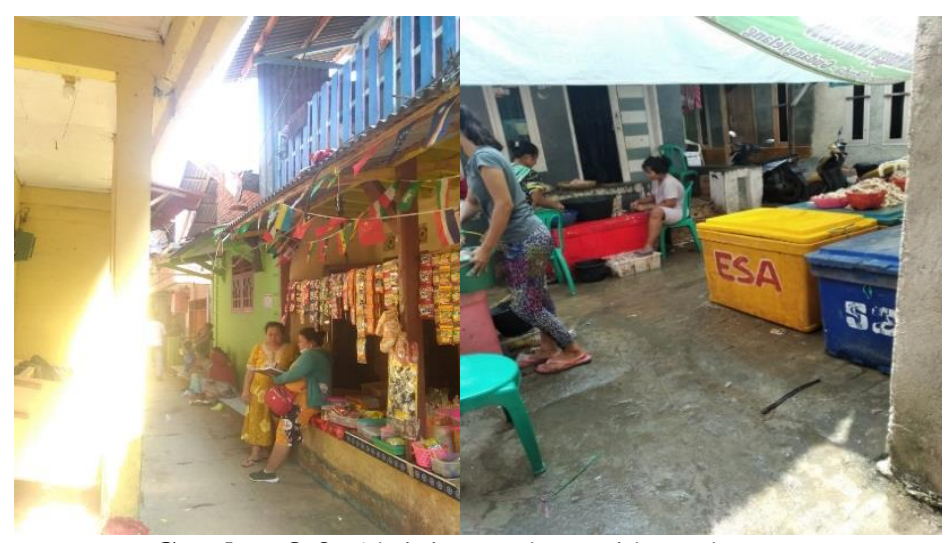

Gambar 8-9. Aktivitas pada Koridor Jalan *) sumber: Observasi Lapangan, 2021

\section{Toilet Umum}

Salah satu ruang bersama lain yang teridentifikasi dalam studi ini adalah toilet umum. Luas rumah yang terbatas pada permukiman nelayan, menyebabkan terdapat rumah-rumah yang tidak memiliki akses sanitasi. Dalam hal ini, untuk memenuhi kebutuhan sehari-hari, terdapat toilet umum yang digunakan secara bersama pada beberapa rumah di permukiman nelayan Kangkung. Adapun toilet umum tersebut memiliki fungsi ruang sosial sebagai ruang pemenuhan kebutuhan dasar terhadap sanitasi.
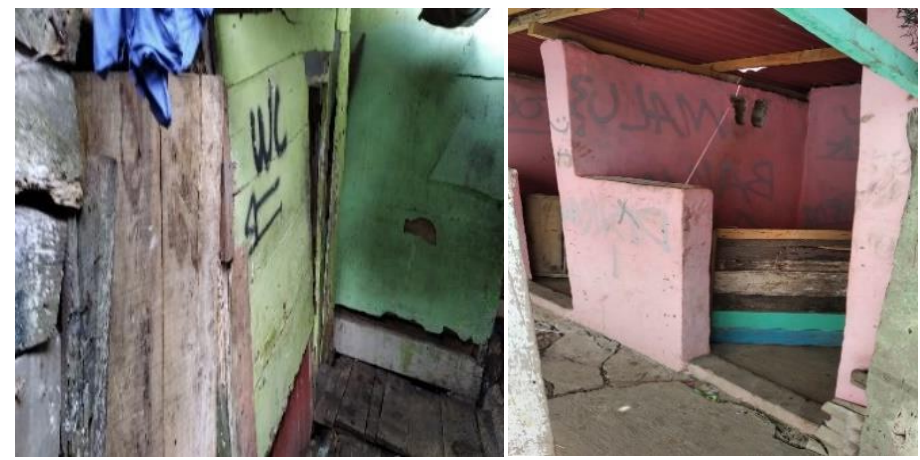

Gambar 10-11. Toilet Umum

*) sumber: Observasi Lapangan, 2021

\section{SIMPULAN}

Berdasarkan hasil observasi lapangan yang dilakukan serta penggalian informasi melalui wawancara, teridentifikasi lima ruang bersama yang terdapat di Kelurahan Kangkung. Ruang bersama ini merupakan ruang yang digunakan secara bersama oleh berbagai karakteristik pengguna, baik nelayan, pedagang, anak-anak, serta ibu-ibu dalam keseharian mereka. Adapun lima ruang bersama tersebut adalah pasar, pelabuhan dan Tempat Pelelangan Ikan (TPI), area tepi laut, koridor jalan dan toilet umum

Selain itu, hasil studi mengidentifikasi setidaknya terdapat tiga fungsi ruang bersama pada permukiman nelayan Kangkung, yaitu sebagai tempat untuk pemenuhan fungsi sosial, fungsi ekonomi, serta gabungan antara fungsi sosial dan ekonomi. Ruang bersama yang berperan untuk pemenuhan kebutuhan sosial terdiri dari area tepi laut, koridor jalan, serta toilet umum, yang digunakan baik untuk berinteraksi, bermain, serta untuk pemenuhan kebutuhan dasar dari masyarakat. Selain itu, ruang bersama yang berfungsi untuk pemenuhan fungsi ekonomi terdiri dari pasar, pelabuhan dan TPI, yang ramai digunakan oleh nelayan, pedagang, pelaku transportasi, serta masyarakat sebagai konsumen, sebagai sumber mata pencaharian, sekaligus sebagai tempat untuk mendapatkan kebutuhan seharihari dengan harga terjangkau. Adapun ruang bersama yang memiliki peran sosial sekaligus ekonomi adalah koridor jalan, yang berperan sebagai tempat berkumpul dan berinteraksi bagi warga, sekaligus menjadi tempat untuk berjualan, menjemur, serta fillet ikan.

Adapun rekomendasi terhadap riset selanjutnya adalah terkait arahan desain ruang bersama yang akomodatif terhadap berbagai jenis kegiatan yang terdapat pada permukiman kumuh. Sehingga, ruang bersama ini dapat diremajakan dan berdampak signifikan bagi berbagai jenis pengguna ruang. Selain itu, penelitian lanjutan juga dapat dilakukan untuk mengkaji lebih mendalam terkait karakteristik ruang bersama berdasarkan perspektif gender (anak-anak, lansia, wanita). Hal ini dilakukan untuk memastikan kebutuhan ruang pada permukiman nelayan memperhatikan aspek inklusifitas yaitu mewadahi seluruh kebutuhan masyarakat dari berbagai kelompok.

\section{DAFTAR PUSTAKA}

Anggito, Albi dan Setiawan, Johan. (2018) Metode Penelitian Kualitatif. Sukabumi: Jejak Publisher.

Heryati. (2009). Penanganan Kawasan Permukiman Kumuh di Kelurahan Limba B Melalui Peremajaan (Renewal). Dipetik pada tanggal 8 September 2021, dari: https://repository.ung.ac.id/get/karyailmiah/118/P enanganan-Permukiman-Kumuh-di-KelurahanLimbah-B-melalui-Peremajaan-Renewel.pdf.

Hoppenbrouwer, Bas. (2019). The Community Effects of Co-living: Exploring opportunities for Dutch developer-led co-living in fostering community building among residents. Dipetik pada tanggal 8 September 2021, dari: https://theses.ubn.ru.nl/bitstream/handle/12345678 9/8521/Hoppenbrouwer\%2C_Bas_2.pdf?sequence $=2$.

Kementerian Pekerjaan Umum dan Perumahan Rakyat. (2016). Peraturan Menteri PUPR No. 02/PRT/M/2016 Tentang Peningkatan Kualitas Terhadap Perumahan Kumuh dan Permukiman Kumuh. Jakarta: Kementerian PUPR. Dipetik pada tanggal 8 September 2021, dari: http://ciptakarya.pu.go.id/bangkim/rp2kpkp/files/P ermen\%20PU\%20No\%202\%20Th\%202016.pdf.

Kementerian Pekerjaan Umum dan Perumahan Rakyat. (2015). Penanganan Kawasan Permukiman Kumuh.: Panduan Penyelenggaraan Infrastruktur 
Hafi Munirwan et al., Identifikasi Karakteristik Ruang Bersama Pada Permukiman Nelayan Untuk Optimalisasi Peremajaan Permukiman dengan Konsep Co-Living (Studi Kasus Kelurahan Kangkung, Kota Bandar Lampung)

Permukiman. Jakarta: Kementerian PUPR.

Dipetik pada tanggal 8 September 2021, dari: http://ciptakarya.pu.go.id/dok/ebook/konsinyasi/V olume $\% 201 . \% 20 \mathrm{Penanganan} \% 20 \mathrm{Kawasan} \% 20 \mathrm{Pe}$ rmukiman\%20Kumuh.pdf.

Munirwan, H., et al. (2020). Peremajaan Lahan Terdampak Tsunami Menjadi Ruang Terbuka Hijau Melalui Pendekatan Perencanaan Kolaboratif di Kota Banda Aceh (Studi Kasus Hutan Kota BNI Tibang dan Taman Kota BNI Trembesi). Jurnal Ilmiah Universitas Batanghari Jambi, 20(2), 463-469. DOI 10.33087/jiubj.v20i2.898.

Rahmawati, Asiana. (2018). Aplikasi SWOT di Kawasan Permukiman Kumuh (Kelurahan Biring Romang). Seminar Ikatan Peneliti Lingkungan Binaan Indonesia, 3, A042-050. doi.org/10.32315/sem.3.a042. 